\title{
Antifungal susceptibility testing of yeast isolated from corneal infections
}

\author{
Testede susceptibilidade a antifúngicos deleveduras isoladas de infecçõescorneais
}

\author{
Vera Lucia Degaspare Monte Mascaro ${ }^{1}$ \\ Ana Luisa Höfling'-Lima ${ }^{2}$ \\ Olga Fishman Gompertz ${ }^{3}$ \\ Maria Cecília Zorat Y $\mathbf{u}^{4}$ \\ Daniel Archimedes da Matta $^{5}$ \\ Arnaldo Lopes Colombo ${ }^{6}$
}

\begin{tabular}{|l|}
\hline ABSTRACT \\
\hline Purpose: To report the antifungal susceptibility profile of yeast isolates \\
obtained from cases of keratitis. Methods: Susceptibility testing of 15 yeast \\
strains isolated from corneal infections to amphotericin B, fluconazole, \\
itraconazole and ketoconazole was performed using the NCCLS broth \\
microdilution assay. Results: Most episodes of eye infections were \\
caused by Candida albicans. The antifungal drugs tested showed the \\
following minimal inhibitory concentration values against yeast isolates: \\
$0.125-0.5 \mu \mathrm{g} / \mathrm{ml}$ for amphotericin B; $0.125->64.0 \mu \mathrm{g} / \mathrm{ml}$ for fluconazole; \\
$0.015-1.0 \mu \mathrm{g} / \mathrm{ml}$ for itraconazole and $0.015-0.125 \mu \mathrm{g} / \mathrm{ml}$ for ketoconazole. \\
Despite the fact that all Candida isolates were judged to be susceptible to \\
azoles, one isolate showed a minimal inhibitory concentration value \\
significantly higher than a $90 \%$ minimal inhibitory concentration of all \\
tested isolates. Rhodotorula rubra was resistant to fluconazole and \\
itraconazole. Conclusions: Despite the fact that most yeast isolates from \\
corneal infections are usually susceptible to amphotericin B and azoles, \\
they exhibit a wide range of minimal inhibitory concentration values for \\
antifungal drugs. The identification of strains at species level and their \\
susceptibility pattern to antifungal drugs should be considered before \\
determining the concentration to be used in topical antifungal formulations \\
in order to optimize therapeutic response in eye infections.
\end{tabular}

Keywords: Eye infections, Keratitis, Antifungal agents, Yeasts infections, Antifungal susceptibility tests.

mology of the Universidade Federal de São Paulo UNIFESP. In charge of the Cornea Sector of the Hospital do Servidor Público Estadual - IAMSPE.

${ }^{2}$ Associate Professor, Department of Ophthalmology of the Universidade Federal de São Paulo - UNIFESP.

3 Associate Professor, Department of Microbiology, Immunology and Parasitology of the Universidade Federal de São Paulo - UNIFESP.

${ }^{4}$ Biomedical Assistant of the Ocular Microbiology Laboratory, Department of Ophthalmology of the Universidade Federal de São Paulo - UNIFESP.

${ }^{5}$ Biologist, Technician responsible for the Mycology Laboratory, Division of Infectious and Parasitic Diseases, Department of Medicine of the Universidade Federal de São Paulo - UNIFESP.

${ }^{6}$ Associate Professor, Department of Infectious and Parasitic Diseases, Department of Medicine of the Universidade Federal de São Paulo - UNIFESP.

Address for correspondence: Arnaldo Lopes Colombo Disciplina de Doenças Infecciosas e ParasitáriasUNIFESP - Rua Botucatu, 740 São Paulo (SP)

CEP 04023-062 - E-mail: Colomboal@terra.com.br

Recebido para publicação em 16.07.2002

Aceito para publicação em 27.11.2002

\section{INTRODUTION}

Fungi are opportunistic agents which rarely infect healthy corneas of immunocompetent individuals. Systemic and local underlying diseases may render the corneal tissues susceptible to infections with these organisms ${ }^{(1)}$. Trauma, specially related to organic materials, topical use of steroids and antibiotics $^{(2-3)}$, contact lens wear, surgical procedures, contamination of eye solutions, inappropriate maintenance of contact lenses ${ }^{(4)}$, systemic infections as well as any disease associated with immunodeficiency are considered risk factors for fungal eye infections ${ }^{(5)}$.

In Brazil, the incidence of fungal eye infections ranges from 3.8 to $10 \%$, depending on the site of the infection, the diagnostic tools available for fungal infections in the medical center and the seasons related to the studied period $^{(6-9)}$.

The occurrence of keratomycosis is of great importance, not only because of diagnostic problems but also due to the severity of clinical manifestations and poor outcome despite antifungal treatment. The severity and progression of the fungal infection usually depend on the existence of
\end{abstract}


previous underlying diseases, impaired local defense mechanisms and the involved fungal species ${ }^{(10-11)}$.

Therapeutic failure rates in fungal keratitis are very high in different series and the poor outcome is related to several factors including: late diagnosis, host's underlying diseases, reduced ocular drug penetration and low antifungal susceptibility of certain etiologic agents ${ }^{(2,10,12-15)}$.

Despite the fact that fungal eye infections continue to be a challenge to ophthalmologists due to the high rates of therapeutic failures ${ }^{(16)}$ observed in different services, we found few studies referring to in vitro antifungal susceptibility testing of clinical fungal isolates obtained from episodes of eye infections ${ }^{(16)}$.

The purpose of this study was to evaluate the antifungal susceptibility profile of yeast isolates from corneal infections using the internationally accepted NCCLS methodology.

\section{METHODS}

From 1996 to 1998, corneal yeast infections were diagnosed in 15 patients attended at the External Eye Disease and Corneal Services of the Department of Ophthalmology, of the Federal University of São Paulo. Isolation of the involved etiologic agent as well as the stocking of the specimens were performed at the Laboratory of Microbiology of this department. The patients' main demographic and clinical data were obtained by reviewing their charts.

All yeast isolates were submitted to species identification and in vitro antifungal susceptibility tests at the Special Mycology Laboratory of the Division of Infectious Diseases of the Department of Medicine.

Identification of the yeast was based on their micromorphology on Cornmeal-Tween 80 agar and their biochemical profile was determined by assimilation and carbohydrate fermentation tests ${ }^{(17)}$.

Antifungal susceptibility tests were performed using the broth microdilution assay according to the methodology recommended by the NCCLS $(1997)^{(18)}$. The following antifungal drugs, supplied by the manufacturers as pure standard compounds, were tested: amphotericin B, fluconazole, itraconazole and ketoconazole. Briefly, the medium used was RPMI-1640, with L-glutamine, without bicarbonate, and buffered at $\mathrm{pH} 7.0$ with 0.165 M MOPS. The yeast inoculum was prepared based on optical density using a spectrophotometer to obtain a yeast concentration of $0.5-2.5 \times 10^{3} \mathrm{cell} / \mathrm{s} / \mathrm{ml}$. The assays were incubated at $35^{\circ} \mathrm{C}$ for $48 \mathrm{~h}$. The minimal inhibitory concentration (MIC) for amphotericin B was considered the lowest tested concentration able to inhibit any visual colony growth. MIC for azoles was considered the lowest concentration able to inhibit 50\% colony growth relative to control.

The breakpoints used for the definition of susceptibility categories are those proposed by the NCCLS and are as follows:
Fluconazole: susceptible if $\mathrm{MIC}<8.0 \mu \mathrm{g} / \mathrm{ml}$, dose dependent susceptibility (DD-S) if MIC from 16.0 to $32.0 \mu \mathrm{g} / \mathrm{ml}$ and resistant if MIC $>64.0 \mu \mathrm{g} / \mathrm{ml}$;

Itraconazole: Susceptible if MIC $<0.125 \mu \mathrm{g} / \mathrm{ml}$, dose-dependent susceptibility if MIC from 0.25 to $0.50 \mu \mathrm{g} / \mathrm{ml}$ and resistant if MIC $>1.0 \mu \mathrm{g} / \mathrm{ml}$.

Due to a lack of consensus about the definition of MIC breakpoint for ketoconazole and amphotericin B, arbitrary values were established according to suggested values of previous studies:

Ketoconazole: susceptible for isolates with $<0.125 \mu \mathrm{g} / \mathrm{ml}$, DD-S for isolates with MIC between 0.25 and $0.50 \mu \mathrm{g} / \mathrm{ml}$ and resistant for isolates with $\mathrm{MIC}>1.0 \mu \mathrm{g} / \mathrm{ml}$;

Amphotericin B: susceptible if MIC $<1.0 \mu \mathrm{g} / \mathrm{ml}$ and resistant if MIC $>2.0 \mu \mathrm{g} / \mathrm{ml}$.

\section{RESULTS}

Clinical and epidemiological characteristics of the evaluated patients are summarized in Table1.

The patients' ages ranged from 10 to 89 years, with a median age of 64 years, $\bar{x}=56.4)$ with 6 episodes $(40 \%)$ occurring in males. It was possible to identify one or more predisposing factors for eye infection in all enrolled patients, with an emphasis on local immunosuppression as well as the use of topical antibiotics.

The species distribution of the yeast isolates, as shown in Table 1, was the following: C. albicans $(53.3 \%), C$. parapsilosis $(20.0 \%)$, C. tropicalis $(20.0 \%)$ and one case of Rhodotorula rubra.

The MIC values of antifungal drugs tested are shown in Table 2.

The MIC values of the antifungal drugs tested against Candida spp isolates ranged from 0.125 to $0.5 \mu \mathrm{g} / \mathrm{ml}$ for amphotericin B, 0.125 to $4.0 \mu \mathrm{g} / \mathrm{ml}$ for fluconazole, 0.015 to 0.25 $\mu \mathrm{g} / \mathrm{ml}$ for itraconazole and $0.015 \mu \mathrm{g} / \mathrm{ml}$ to $0.06 \mu \mathrm{g} / \mathrm{ml}$ for ketoconazole.

Using the susceptibility breakpoints suggested by the NCCLS ${ }^{(21)}$ for the studied antifungal drugs, it was possible to state that all samples were susceptible to amphotericin B. Regarding azoles, the Rhodotorula rubra isolate was resistant to fluconazole and itraconazole. Similarly, one C. albicans strain exhibited dose-dependent susceptibility to itraconazole. It should be mentioned that although all Candida isolates were susceptible to fluconazole, one $C$. albicans isolate showed a MIC value of $2.0 \mu \mathrm{g} / \mathrm{ml}$ (patient 3) for fluconazole and one $C$. parapsilosis strain exhibited a MIC value of $4.0 \mu \mathrm{g} / \mathrm{ml}$ for fluconazole (patient 10 ).

Table 3 summarizes the MIC ranges, MIC- $50 \%$ (concentration able to inhibit $50 \%$ colony growth (or colony formation) of the tested samples) and MIC-90\% (concentration able to inhibit $90 \%$ colony growth (or colony formation) of the tested samples) values of antifungal drugs tested against all C. albicans isolates. 


\begin{tabular}{|c|c|c|c|c|c|}
\hline No. & Age (years) & Sex & Predisposing factors & Site & Microorganism \\
\hline 1 & 74 & $\mathrm{~F}$ & Corneal surgery - Tx & Cornea & C. albicans \\
\hline 2 & 45 & $\mathrm{~F}$ & Trauma - Foreing body & Cornea & C. albicans \\
\hline 3 & 81 & M & Exposed ulcer & Cornea & C. albicans \\
\hline 4 & 89 & $\mathrm{~F}$ & Senility & Cornea & C. albicans \\
\hline 5 & 69 & M & Corneal perforation & Cornea & C. albicans \\
\hline 6 & 47 & M & Endophthalmitis/keratitis & Cornea & C. albicans \\
\hline 7 & 44 & $\mathrm{~F}$ & Immunosuppression Sjögren S. & Cornea & C. albicans \\
\hline 8 & 44 & M & Immunosuppression HIV + & Cornea & C. albicans \\
\hline 9 & 70 & $\mathrm{~F}$ & Corneal surgery - ulcer & Cornea & C. parapsilosis \\
\hline 10 & 83 & $\mathrm{~F}$ & Use of topical medication & Cornea & C. parapsilosis \\
\hline 11 & 48 & $\mathrm{~F}$ & Corneal surgery - Tx & Cornea & C. parapsilosis \\
\hline 12 & 14 & M & Trauma & Cornea & C. tropicalis \\
\hline 13 & 64 & $\mathrm{~F}$ & Surgery - Tx & Cornea & C. tropicalis \\
\hline 14 & 64 & $\mathrm{~F}$ & Surgery - Tx & Cornea & C. tropicalis \\
\hline 15 & 10 & M & Dermatological alteration & Cornea & Rhodotorula rubra \\
\hline
\end{tabular}

\begin{tabular}{|c|c|c|c|c|c|}
\hline \multirow[b]{2}{*}{ No. } & \multicolumn{4}{|c|}{ MIC values $(\mu \mathrm{g} / \mathrm{ml})$} & \multirow[b]{2}{*}{ Microorganisms } \\
\hline & Amphotericin-B & Fluconazole & Itraconazole & Ketoconazole & \\
\hline 1 & 0.25 & 0.5 & 0.03 & 0.015 & C. albicans \\
\hline 2 & 0.25 & 2.0 & $0.25(\mathrm{I})$ & 0.06 & C. albicans \\
\hline 3 & 0.125 & 0.25 & 0.015 & 0.015 & C. albicans \\
\hline 4 & 0.5 & 0.25 & 0.03 & 0.03 & C. albicans \\
\hline 5 & 0.125 & 0.125 & 0.06 & 0.015 & C. albicans \\
\hline 6 & 0.5 & 0.125 & 0.015 & 0.015 & C. albicans \\
\hline 7 & 0.25 & 0.125 & 0.015 & 0.015 & C. albicans \\
\hline 8 & 0.5 & 0.25 & 0.03 & 0.03 & C. albicans \\
\hline 9 & 0.25 & 0.5 & 0.06 & 0.015 & C. parapsilosis \\
\hline 10 & 0.125 & 4.0 & 0.06 & 0.06 & C. parapsilosis \\
\hline 11 & 0.5 & 0.5 & 0.03 & 0.015 & C. parapsilosis \\
\hline 12 & 0.25 & 0.25 & 0.015 & 0.015 & C. tropicalis \\
\hline 13 & 0.125 & 1.0 & 0.06 & 0.03 & C. tropicalis \\
\hline 14 & 0.25 & 0.125 & 0.015 & 0.015 & C. tropicalis \\
\hline 15 & 0.25 & $>64 @$ & $1.0 ®$ & 0.125 & R. rubra \\
\hline
\end{tabular}

\section{DISCUSSION}

Although mycotic keratitis may occur in a variety of climatic zones, it seems to be more common in regions with subtropical or tropical climate, both found in the greater part of Brazil. Fungi accounted for 5\% of all infectious keratitis (61 of 1113 patients) as documented in the Laboratory of External Diseases of the Department of Ophthalmology, Federal University of São Paulo - Escola Paulista de Medicina, from 1995 to 1998 (data not shown). Fusarium genus (51\%), Candida spp (23\%) and Aspergillus spp (8.19\%) were the most commonly isolated agents of fungal keratitis ${ }^{(19)}$.

In the present study, the clinical and microbiological characteristics of documented yeast keratitis were evaluated at the institution. In agreement with other series, all patients with yeast corneal infections presented with at least one predisposing factor to corneal fungal infections, including the use of antibiotics and corticoids, systemic immunosuppression, advanced age, trauma or previous surgery.

Regarding the etiology of the eye infections, 53.3\% was keratitis caused by $C$. albicans. This finding is in agreement with previous publications addressing the etiology of eye infections. Rosa et al. ${ }^{(19)}$ reviewed the charts of 125 patients with fungal keratitis in South Florida for a period of 10 years (1982-1992) and observed that the Candida genus accounted for $12 \%$ (16 cases) of all infections. Regarding species, C. albicans corresponded to $25 \%^{(20)}$. Wakisaka et al, after analyzing the cultures of corneal ulcers in 263 patients, from 
September,1986 to February,1998, found 10 episodes of mycotic keratitis $(4 \%)$ where 2 cases were caused by $C$. albicans isolates ${ }^{(6)}$. In this laboratory, a retrospective study was conducted to evaluate 671 cases of infectious corneal ulcers reported during a period of 10 years (January, 1981 to December, 1991). The authors found that 64 episodes $(1.5 \%)$ were caused by fungi and Candida sp accounted for $12.5 \%$ of all identified fungal isolates ${ }^{(9)}$.

It is interesting that we were able to identify one case of keratitis due to Rhodotorula rubra, an agent of low pathogenicity and virulence, causing corneal infection. We did not find any previous report of keratitis caused by this yeast pathogen. However, different authors view this agent as being an emergent pathogen among superficial and systemic fungal infections ${ }^{(21-23)}$.

To enhance drug penetration and clinical efficacy, keratitis therapy involves the use of topic, systemic and subconjunctival medication after removal of the corneal epithelium. Topical amphotericin $\mathrm{B}$ is considered to be the drug of choice for the treatment of mycotic keratitis ${ }^{(24)}$. The range of amphotericin $B$ concentrations in topic formulations used for the treatment of corneal infections is very broad. Experiments have shown that concentrations between 0.015 and $1 \%$ may be used. Amphotericin $\mathrm{B}$ is toxic when administrated by the subconjunctival route and severe complications, including conjunctival necrosis, may occur ${ }^{(14)}$. Intravenous use of amphotericin B is limited in the case of fungal keratitis because, besides all the systemic adverse effects, it penetrates the cornea minimally reaching low levels in the aqueous humor ${ }^{(15)}$. After evaluating the susceptibility profile of amphotericin B obtained with the tested clinical yeast isolates, we found that all were susceptible to this drug; however, a MIC variation of $0.125 \mu \mathrm{g} / \mathrm{ml}$ to $0.5 \mu \mathrm{g} / \mathrm{ml}$ was observed. Considering the range of MIC obtained with amphotericin B, to optimize the clinical efficacy of topic formulations and avoid toxicity, it would be reasonable to propose that patients infected with agents with higher susceptibility to this drug should be treated with lower concentrations and vice-versa. This notion needs to be validated by clinical and experimental studies which are only possible with the use of susceptibility tests applied to ocular pathogens.

Ketoconazole is an imidazole to be used orally, truly requiring systemic absorption which depends on the gastric acidity. Topical formulations of ketoconazole may be prepared at a 1 to $5 \%$ concentration, reaching good therapeutic corneal levels. Since ketoconazole can be administered orally and shows a wide antifungal spectrum, the drug is a natural candidate for use in the systemic treatment of keratomycosis, either alone or in association with topic preparations ${ }^{(15)}$. In the present study, the isolates were all susceptible to ketoconazole but exhibited MIC values ranging from 0.015 to $0.125 \mu \mathrm{g} / \mathrm{ml}$, a variation of almost 100 times the inhibitory potential of this drug in relation to the examined pathogens.

Fluconazole is a triazole exhibiting excellent tolerability and intraocular penetration. However, its antifungal activity is basically restricted to the genus Candida, C. neoformans isolates and dermatophytes. It is important to note that fluconazole has no antimycotic activity against Aspergillus spp and Fusarium spp, the agents which usually cause keratitis ${ }^{(15,25)}$. Regarding fluconazole MIC, we obtained a large variation of values against the tested ocular pathogens, including one $C$. albicans strain that exhibited a MIC value higher than the MIC-90 for the 8 tested samples (Table 3). On the other hand, there was one episode of $R$. rubra keratitis in which the isolate exhibited in vitro resistance to fluconazole and itraconazole. These data reinforce the potential role of susceptibility tests in defining a rational therapeutic strategy for fungal keratitis.

Itraconazole is a triazole with a large spectrum of antifungal activity including activity against the genus Candida, $C$. neoformans isolates, as well as dermatophytes, Aspergillus spp and dimorphic fungi. However, the capsule formulation available shows bioavailability limitations affecting its serum levels and tissular distribution. Therefore, in spite of its high tolerability and broad spectrum, its clinical ophthalmologic use is restricted ${ }^{(25-26)}$. In the present study, MIC values for itraconazole were quite lower than those recorded for fluconazole when we evaluated Candida spp specimens. These data reinforce the therapeutic potential of itraconazole in fungal keratitis, whose clinical applicability could be broadened with the recent advent of oral and parenteral solutions of this derivative solubilized in cyclodextrin ${ }^{(27)}$.

Recently, several studies have called attention to the occurrence of primary or acquired infections due to yeast resistant to antifungal drugs. Such reports are more frequent among patients with AIDS or malignant hematological diseases, situations in which the prophylactic or therapeutic use of antimycotics is more disseminated ${ }^{(28-30)}$ The literature includes many studies which evaluate the susceptibility profile of yeast isolates from different biological fluids and tissues; however, none were found describing the antifungal susceptibility profile of yeast isolates from ocular infections ${ }^{(31-35)}$.

Considering the high therapeutic failure rate associated with ocular fungal infections, the investigation of the antifun-

\begin{tabular}{|c|c|c|c|c|}
\hline Variables/Antifungals & Amphotericin B & Fluconazole & Itraconazole & Ketoconazole \\
\hline MIC ranges $(\mu \mathrm{g} / \mathrm{ml})$ & $0.125-0.5$ & $0.125-2.0$ & $0.015-0.25$ & $0.015-0.06$ \\
\hline MIC - $50 \%$ & 0.25 & 0.25 & 0.03 & 0.015 \\
\hline MIC - $90 \%$ & 0.50 & 0.50 & 0.06 & 0.03 \\
\hline
\end{tabular}


gal susceptibility profile of ocular fungal pathogens may be useful to identify antifungal resistance as a possible risk factor for unfavorable outcome. Similarly, to optimize the toxicity/therapeutic efficacy ratio with respect to ocular infections, it is reasonable to suggest that MIC values of antifungal drugs should be considered before defining the best concentration of the drug to be used in topic formulations. The actual benefit of such management should be evaluated by further clinical studies.

\section{CONCLUSIONS}

In conclusion, in spite of the fact that most yeast isolates from ocular infections were found to be susceptible to amphotericin B and azoles, a wide variation of antifungal MIC values were obtained with the various tested pathogens. These data provide a warning to reference laboratories associated with Ophthalmology Services that they should be prepared not only for the accurate identification of the fungi found in biological fluids, but also for determination of their susceptibility to antifungal drugs as an additional tool to support therapy.

\section{RESUMO}

Objetivo: Relatar resultados e avaliar a aplicabilidade do teste de suscetibilidade a antifúngicos de leveduras isoladas de infecções corneais oculares. Métodos: Realizou-se teste de suscetibilidade pelo método de microdiluição em caldo, padronizado pelo NCCLS-EUA, em 15 amostras de leveduras de infecções corneanas a anfotericina B, fluconazol, itraconazol e ketoconazol. Resultados: A maioria dos episódios de infecção corneal foi causada por Candida albicans. As drogas antifúngicas testadas exibiram valores de concentração inibitória mínima (CIM) para as leveduras isoladas: $0,125-0,5 \mu \mathrm{g} / \mathrm{ml}$ para anfotericina B; 0,125->64,0 $\mu \mathrm{g} / \mathrm{ml}$ para fluconazol; 0,015-1,0 $\mu \mathrm{g} / \mathrm{ml}$ para itraconazol e $0,015-0,125 \mu \mathrm{g} / \mathrm{ml}$ para ketoconazol. Apesar de todas as amostras terem sido suscetíveis aos azólicos, uma exibiu valor de concentração inibitória mínima significantemente maior do que a concentração inibitória mínima 90\% de todas as amostras testadas. Rhodotorula rubra foi resistente a fluconazol e itraconazol. Conclusão: Apesar da maioria das leveduras isoladas de infecções corneais serem usualmente suscetíveis a anfotericina B e azólicos, observa-se ampla variação de valores de concentração inibitória mínima obtidas com as diferentes drogas antifúngicas testadas. A identificação das cepas e a determinação do padrão de suscetibilidade devem ser consideradas antes da determinação da concentração das drogas a ser empregada em formulações antifúngicas tópicas com o objetivo de otimizar a resposta terapêutica às infecções oculares.

Descritores: Infecções oculares; Ceratites; Antifúngicos; Infecções por leveduras; Testes de suscetibilidade a antifúngicos.

\section{REFERENCES}

1. Thomas P. Mycotic keratitis - an underestimated mycosis. J Med Vet Mycol 1994;32:235-56.

2. Sato EH, Burnier Jr M. Belfort-Mattos R, Nascentes MN, Rigueiro MP. Transplante de córnea "a quente" em úlcera micótica. Arq Bras Oftalmol 1989;52:56-60.

3. Cha SB, Fischman O, Barros PSM, Mikoves R. Microbiota fúngica conjuntival de pacientes com síndrome de imunodeficiência adquirida (AIDS). Arq Bras Oftalmol 1990;3:80-90.

4. Stern WH, Tamura E, Jacobs RA, Pons VG, Stone RD, O’Day DM, et al. Epidemic postsurgical Candida parapsilosis endophthalmitis clinical findings and management of 15 consecutive cases. Ophthalmology 1985;92:1701-9.

5. Foster C. Fungal keratitis. In:Albert DM, editor. Principles and practice of ophthalmology: clinical practice. Philadelphia: W B Saunders; 1994. p.171-9.

6. Wakisaka E, Ferreira MA, Rocha FJ, Freitas LL, Guidugli T, Lima ALH. Cultura de material provindo de úlceras de córnea em laboratório de referência. Arq Bras Oftalmol 1990;53:196-200.

7. Chaib AR, Freitas D, Scarpi MJ, Guidugli T. Pesquisa laboratorial em endoftalmite. Arq Bras Oftalmol 1997;60:250-7.

8. Morales PC, Sousa SJF, Furlan EMR. Estudo epidemiológico de úlceras de córnea na região de Ribeirão Preto [resumo]. Arq Bras Oftalmol 1993;56:43.

9. Vieira LA, Carneiro MDF, Guidugli T, Scarpi M. Incidência de úlceras corneanas fúngicas no laboratório de doenças externas oculares da Escola Paulista de Medicina [resumo]. Arq Bras Oftalmol 1992;55:180.

10. Abad JC, Foster CS. Fungal keratitis. Int Ophthalmol Clin 1996;36:1-15.

11. Wong TY, Ng TP, Fong KS, Tan DT. Risk factors and clinical outcomes between fungal and bacterial keratitis: A comparative study. CLAO J 1997;23:275-81.

12. O'Day DM, Ray WA, Head WS, Robinson RD. Influence of the corneal epithelium on the efficacy of topical antifungal agents. Invest Ophthalmol Vis Sci $1984 ; 25: 855-9$.

13. Lima ALH, Belfort Jr R, Foster R, Parel JM, Rebell G. Penetração de diferentes antimicóticos na córnea humana- estudo "in vitro". Arq Bras Oftalmol 1987;50:80-7.

14. O'Day DM, Ray WA, Robinson RD, Head WS, WilliamsTE. Differences in response in vivo to amphotericin B among Candida albicans strains. Invest Ophthalmol Vis Sci 1991;32:1569-72.

15. O'Day DM. Seletion of appropriate antifungal therapy. Cornea 1987;6:238-47.

16. Foster C. Fungal keratitis. Infect Dis Clin North Am 1992;6:851-7.

17. Larone D. Medically important fungi: a guide to identification. Washington: American Society for Microbiology; 1995.

18. Andrade AJ, Vieira LA, Lima AL, Yu MC, Gompertz OF, Freitas D, et al. Análise laboratorial de ceratites fungicas em serviço universitário. Arq Bras Oftalmol 2000;63:59-63.

19. Rosa RH, Miller D, Alfonso EC. The changing spectrum of fungal keratitis in South Florida. Ophthalmology 1994;101:1005-13.

20. Francois J, Rijsselaere M. Corneal infections by Rhodotorula. Ophthalmologica 1979;178:241-9.

21. Colombo AL, Dantas LS, Abramczyk ML Cypriano M, Fishman O, Iazzetti $\mathrm{AV}$, et al., Rhodotorula glutinis fungemia: a case report and literature review. Braz J Infect Dis 1997;1:204-7.

22. Marinová I, Szabadosová V, Brandeburová O, Krcméry V. Rhodotorula spp. fungemia in an immunocompromised boy after neurosurgey successfully treated with miconazole and 5-flucytosine: case report and review of the literature. Chemotherapy 1994;40:287-9.

23. O'Day DM, Robinson R, Head WS. Efficacy of fungal agents in the cornea. I. A comparative study. Invest Ophthalmol Vis Sci 1983;24:1098-102.

24. O'Day D. New antifungal drugs in ophthalmology. Int Ophthalmol Clin 1996;36:45-51.

25. Sheehan DJ, Espinel-Ingroff A, Moore LS, Webb CD. Antifungal susceptibility testing of yeasts: A brief overview. Clin Infect Dis 1993;17 (Suppl 2):S494-500.

26. Vandewoude K, Vogelaers D, Decruyenaere J, Jaqmin P, De Beule K, Van Peer A, et al. Concentrations in plasma and safety of 7 days on intravenous itraconazole followed by 2 weeks of oral intraconazole solution in patients in intensive care units. Antimicrob Agents Chemother 1997;41:2714-8.

27. Milan EP, Burattini MN, Kallás EG, Fischmann O, Costa PRO, Colombo AL Azole resistence among oral Candida species isolates from AIDS patients under ketoconazole exposure. Diagn Microbiol Infect Dis 1998;32:211-6.

28. Chronister C. Review of external ocular disease associated with aids and HIV infection. Optom Vis Sci 1996;73:225-30. 
29. Mselle J. Fungal keratitis as an indicator of HIV infection in Africa. Trop Doct 1999;29:133-5.

30. Pfaller MA, Diekema DJ, Jones RN, Sader HS, Fluit AC, Hollis RJ, Messer SA. International surveillance of bloodstream infections due to Candida species, frequency of ocurrence and in vitro susceptibilities to fluconazole, ravuconazole, and voriconazole of isolates collected from 1997 through 1999 in the SENTRY Antimicrobial Surveillance Program. J Clin Microbiol 2001;39:3254-9.

31. Pfaller MA, Jones RN, Doern GV, Sader HS, Messer SA, Houston A, et al. Bloodstream infections due to Candida species: SENTRY antimicrobial surveillance program in North America and Latin America, 1997-1998. Antimicrob Agents Chemother 2000; 44:747-51.

32. Pfaller MA, Jones RN, Messer SA, Edmond MB, Wenzel RP. National surveillanceof nosocomial blood stream infection due to species of Candida other than Candida albicans: frequency of ocurrence and antifungal susceptibility in the SCOPE Program. Diagn Microbiol Infect Dis 1998;30:121-9.

33. Colombo A. Epidemiology and treatment of hematogenous candidiasis: a Brazilian perspective. Braz J Infect Dis 2000;4:113-8.

34. Barchiesi F, Colombo AL, McGough DA, Forthergill AW, Rinaldi MG. In vitro activity of a new antifungal triazole, DO870, against Candida albicans isolates from cavities of patients infected with human immunodeficiency virus. Antimicrob Agents Chemother 1994;38:2553-6.

35. Branchini ML, Aoki FH, Colombo AL, Taguchi H, Yamamoto L, Miyazi M. Effect of antifungal agents on Candida spp, and Pichia anomala isolated from oropharyngeal candidiasis of AIDS patients in a University Hospital in Brazil. Braz J Infect Dis 1998;2:187-96.

\section{CURSO DE EXAMES COMPLEMENTARES EM OFTALMOLOGIA}

\section{2 e 13 de dezembro de 2.003}

Promoção: Centro de Estudos do Instituto CEMA
R. do Oratório, 1.369
São Paulo - SP

INFORMAÇÕES: Tel.: (11) 6602-4034

E-mail: centrodeestudos@cemahospital.com.br 